\title{
Operational Environmental Monitoring Program Quality Assurance Project Plan
}

\author{
C. J. Perkins
}

Date Published

August 1994

\author{
DISCLAIMER
}

This report was prepared as an account of work sponsored by an agency of the United States Government. Neither the United States Government nor any agency thereof, nor any of their employees, makes any warranty, express or implied, or assumes any legal liability or responsibility for the accuracy, completeness, or usefulness of any information, apparatus, product, or process disclosed, or represents that its use would not infringe privately owned rights. Reference herein to any specific commercial product, process, or service by trade name, trademark, manufacturer, or otherwise does not necessarily constitute or imply its endorsement, recommendation, or favoring by the United States Government or any agency thereof. The views and opinions of authors expressed herein do not necessarily state or reflect those of the United States Government or any agency thereof.

Prepared for the U.S. Department of Energy

Office of Environmental Restoration and

Waste Management

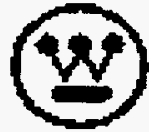

Westinghouse

P.O Box 1970

Hanford Company Richland, Washington

Hanford Operations and Engineering Contractor for the

U.S. Department of Energy under Contract DE-AC06-87RL10930

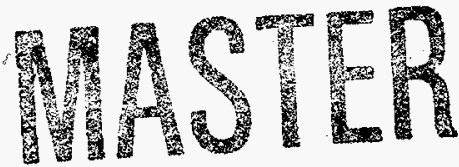

Approved for Public Release 


\section{DISCLAIMER}

Portions of this document may be illegible in electronic image products. Images are produced from the best available original document. 


$$
\text { WHC-EP-0538-2 }
$$

OPERATIONAL ENVIRONMENTAL MONITORING PROGRAM QUALITY ASSURANCE PROJECT PLAN

Prepared by:
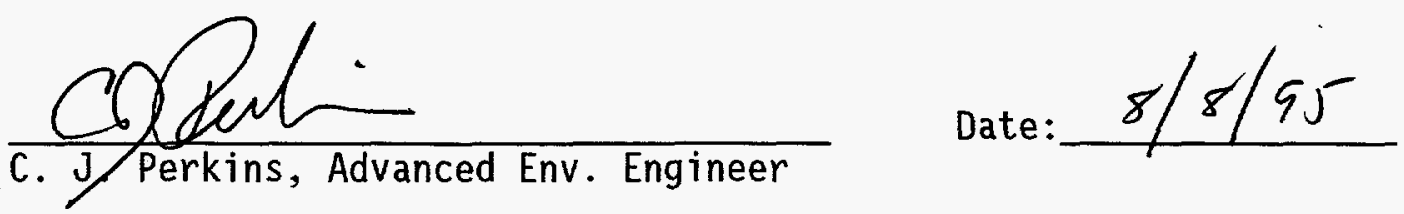

Reviewed by:

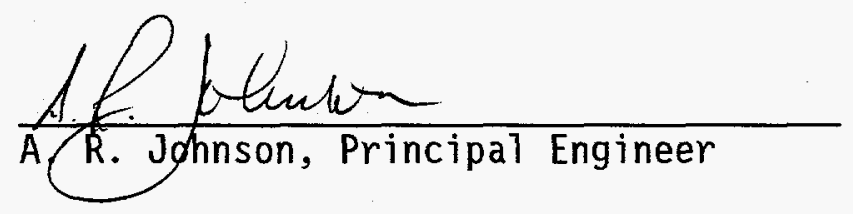

Date: $08-08-95$

Approved by:

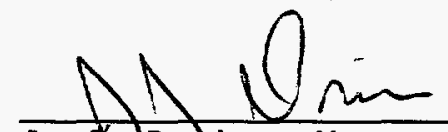

J.J. Don ian, Manager

Environmental Monitoring \& Investigations

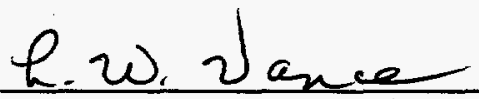

L. W. Vance, Principal QA Engineer Analytical and Environmental QA

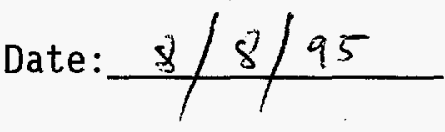

Date: $0 / 8 / 95$ 


\section{RELEASE AUTHORIZATION}

Document Number: WHC-EP-0538-2

Document Title: Operational Environmental Monitoring Program Quality Assurance Project Plan

Release Date: $\quad$ August 18, 1995

This document was reviewed following the procedures described in WHC-CM-3-4 and is:

APPROVED FOR PUBLIC RELEASE

WHC Information Release Administration Specialist:

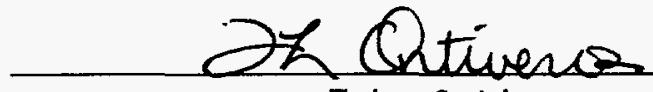

August 18, 1995

T.L. Ontiveros 
WHC-EP-0538-2

\title{
QUALITY ASSURANCE PROJECT PLAN
}

\author{
C. J. Perkins
}

\section{ABSTRACT}

This Quality Assurance Project Plan addresses the quality assurance requirements for the activities associated with the preoperational and operational environmental monitoring performed by Westinghouse Hanford Company as it implements the Operational Environmental Monitoring program. This plan applies to all sampling and monitoring activities performed by Westinghouse Hanford Company in implementing the Operational Environmental Monitoring program at the Hanford Site.

This Quality Assurance Project Plan is required by U.S. Department of Energy Order 5400.1 (DOE 1988a) as a part of the Environmental Monitoring Plan (DOE-RL 1994) and is used to define:

- Environmental measurement and sampling locations used to monitor environmental contaminants near active and inactive facilities and waste storage and disposal sites

- Procedures and equipment needed to perform the measurement and sampling

- Frequency and analyses required for each measurement and sampling location

- Minimum detection level and accuracy

- Quality assurance components

- Investigation levels. 
WHC-EP-0538-2

The OEM program for the Hanford Site is conducted in accordance with the requirements of U.S. Department of Energy Orders 5400.1 (DOE 1988a), 5400.5 (DOE 1990), 5484.1 (DOE 1981), and 5820.2A (DOE 1988b), and DOE/EH-0173T (DOE 1991). It is Westinghouse Hanford Company's policy to manage and conduct activities at the Hanford Site in a cost-effective and environmentally responsible manner that is in compliance with the letter and spirit of these regulations and other environmental regulations, statutes, and standards. 
WHC-EP-0538-2

\section{CONTENTS}

1.0 INTRODUCTION . . . . . . . . . . . . . . . . 1

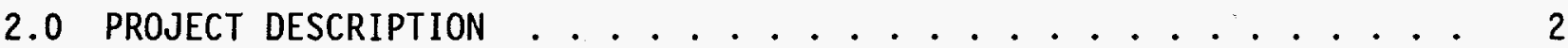

2.1 GENERAL OBJECTIVES .................. 2

2.2 MONITORING ACTIVITIES DESCRIPTION . . . . . . . 3

2.3 APPLICABILITY TO WESTINGHOUSE HANFORD COMPANY QUALITY ASSURANCE PROGRAM ................... 4

3.0 PROJECT ORGANIZATION AND RESPONSIBILITIES . . . . . . . . . 5 3.1 PROJECT MANAGEMENT . . . . . . . . . . . . . . . . 5

3.2 SUPPORTING ORGANIZATIONS . . . . . . . . . . . . . 5

3.3 ANALYTICAL LABORATORIES ................. . . 6

3.4 OTHER SUPPORT CONTRACTORS . . . . . . . . . . 6

4.0 QUALITY ASSURANCE OBJECTIVES FOR MEASUREMENTS . . . . . . . . . . . 7

4.1 ANALYTES OF INTEREST AND ANALYTICAL METHOD SELECTION . . . . . 7

4.2 CONTRACTUAL QUANTITATION LIMITS AND RANGES FOR ANALYTICAL

PRECISION AND ACCURACY .............. . . 7

4.3 REPRESENTATIVENESS, COMPLETENESS, AND COMPARABILITY . . . . 8

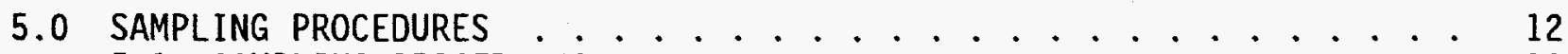

5.1 SAMPLING PROCEDURES ............... 12

5.2 OTHER SUPPORTING PROCEDURES . . . . . . . . . . . . . . . 12

5.3 PROCEDURE APPROVALS AND CONTROL . . . . . . . . . . 12

5.3.1 Westinghouse Hanford Procedures ......... 12

5.3.2 Participant Contractor/Subcontractor Procedures . . . . 12

5.4 PROCEDURE ADDITIONS AND CHANGES .............. 12

5.5 SAMPLING SCHEDULE . . . . . . . . . . . . . 13

6.0 SAMPLE CUSTODY . . . . . . . . . . . . . . 14

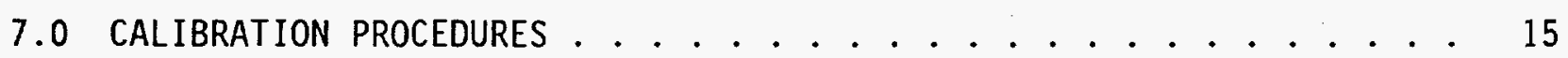

8.0 ANALYTICAL PROCEDURES ..................... 16

9.0 MONITORING AND REPORTING CRITERIA . . . . . . . . . . . . 17

10.0 DATA REDUCTION, VALIDATION, AND REPORTING ......... 18

10.1 DATA REDUCTION AND DATA PACKAGE PREPARATION . . . . . . 18

10.2 VALIDATION . . . . . . 18

10.3 FINAL REVIEW AND RECORDS MANAGEMENT CONSIDERATIONS . . . . 19

11.0 INTERNAL QUALITY CONTROL . . . . . . . . . . . . 20

11.1 REPLICATE SAMPLING . . . . . . . . . . . . 20

11.2 LABORATORY ANALYSES .................. . . . . 20

12.0 SYSTEM AUDITS . . . . . . . . . . . . . . 22

13.0 PReventive Maintenance . . . . . . . . . . . . . 23

14.0 DATA ASSESSMENT PROCEDURES . . . . . . . . . . . . 24 
15.0 CORRECTIVE ACTION ........................ 25

16.0 QUALITY ASSURANCE REPORTS ................ 26

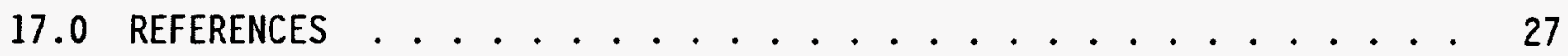

\section{LIST OF TABLES}

4-1 Preferred Analytical Methods . . . . . . . . . . . . . 9

4-2 Supporting Procedures for the Operational

Environmental Monitoring Program ............. 11 


\section{LIST OF TERMS}

BHI Bechtel Hanford, Inc.

CFR Code of Federal Regulations

DOE U.S. Department of Energy

Ecology Washington State Department of Ecology

EMI

EMP

EPA

HTS

OEM

PNL

QA

QAI

QAPjP

$Q C$

QI

QR

$\mathrm{RC}$

$\mathrm{RL}$

WAC

WDOH

Environmental Monitoring and Investigations

Environmental Monitoring Plan

U.S. Environmental Protection Agency

Hanford Technical Services

Operational Environmental Monitoring

Pacific Northwest Laboratory

quality assurance

quality assurance instruction

quality assurance project plan

quality control

quality instruction

QA/QC requirement

Radiological Control

U.S. Department of Energy, Richland Operations Office

WHC Washington Administrative Code Washington State Department of Health Westinghouse Hanford Company 
WHC-EP-0538-2

This page intentionally left blank. 


\subsection{INTRODUCTION}

The U.S. Department of Energy (DOE) Order 5400.1, General Environmental Protection Program (DOE 1988a), required DOE sites to prepare an environmental monitoring plan (EMP). The revised Environmental Monitoring Plan, DOE/RL-91-50, Revision 1 (DOE-RL 1994), was issued on November 9, 1994.

According to the guidance provided in DOE Order 5400.1 (DOE 1988a), each DOE site, facility, or activity that uses, generates, releases, or manages significant quantities of hazardous materials shall provide a written EMP. This EMP must identify and discuss two major activities: effluent monitoring and environmental surveillance.

This quality assurance project plan (QAPjP) addresses the quality assurance (QA) implementation of the OEM surveillance program as part of the overall EMP. 
WHC-EP-0538-2

\subsection{PROJECT DESCRIPTION}

\subsection{GENERAL OBJECTIVES}

The Operational Environmental Monitoring (OEM) program provides facilityspecific environmental monitoring to protect the environment adjacent to facilities under the responsibility of Westinghouse Hanford Company (WHC) or Bechtel Hanford, Inc. (BHI), to ensure compliance with WHC and BHI requirements and local, state, and federal environmental regulations.

The objectives of the OEM program are to evaluate the following:

- Compliance with DOE, the U.S. Environmental Protection Agency (EPA), the Washington State Department of Ecology (Ecology), the Washington State Department of Health (WDOH), and internal WHC and BHI environmental radiation protection requirements and guides

- Performance of radioactive waste confinement systems

- Trends of radioactive materials in the environment at and adjacent to nuclear facilities and waste disposal sites.

Specifically, the OEM program is developed to:

- Monitor all inactive, existing, and new low-level waste disposal sites to assess both radiological and nonradiological hazards (DOE Order 5820.2A).

- Determine the effectiveness of effluent treatment and controls in reducing effluents and emissions (DOE/EH-0173T and DOE/EV/1830-T5).

- Detect and quantify unplanned releases (DOE/EH-0173T) [Tit]e 40 Code of Federal Regulation (CFR) Part 302] [Washington Administrative Code (WAC) 173-303-145] (DOE Orders 5000.3A and 5484.1).

- Monitor fugitive emissions and diffuse sources from contaminated areas for compliance with the "National Emission Standards for Hazardous Air Pollutants" (40 CFR 61), (DOE/EH-0173T), Toxic Air Emissions Inventory (40 CFR 265, Subparts AA and B13), State Operating Permit Program (40 CFR 70), and Source Registration (WAC 246-247).

- Monitor all surplus facilities before and during decontaminating or decommissioning (DOE Order 5820.2A).

- Monitor new and existing sites, processes, and facilities for potential impacts and releases (DOE Orders 5400.1 and 5484.1 , and DOE/EH-0173T).

- Monitor and assess radioactive contamination and potential exposure to employees and the public (DOE Orders 5400.1 and 5400.5).

The purpose and justification for the 0EM program is contained in WHC-CM-7-5, Environmental Compliance. 
WHC-EP-0538-2

The primary justification for the OEM program includes the following:

- The OEM program provides a level of ensurance to WHC that the effluent and contamination controls for the various facilities and waste sites are effective.

- The OEM program monitors a diversity of operations, activities, and programs managed by several different WHC organizations.

Accordingly, program direction and integration for near-facility environmental monitoring activities are needed to ensure consistency, technical quality, and cost effectiveness.

- The OEM program also provides additional ensurance beyond that provided by the Occupational Health and Safety Program that working on site is safe and that visitors can safely tour the site.

It is WHC's policy to manage and conduct activities at the Hanford Site in a cost-effective and environmentally responsible manner that is in compliance with the letter and spirit of applicable environmental statutes, regulations, and standards. WHC shall monitor and control fugitive emissions and diffuse sources from radioactively contaminated areas. In addition, WHC shall ensure that activities are conducted to protect employees, the public, the environment, and government property.

This QAPJP identifies the requirements and specifies the procedures used to implement the OEM program. Responsibilities are defined for those WHC personnel involved in environmental monitoring. WHC personnel shall use this QAPjP to ensure that the OEM program is conducted in a consistent manner.

\subsection{MONITORING ACTIVITIES DESCRIPTION}

The specific OEM program monitoring activities performed by WHC are defined in WHC-CM-7-5, Environmental Compliance Manual, and WHC-CM-7-4, Operational Environmental Monitoring, and generally fail into one or more of the following four categories:

- Monitoring of inactive and active waste storage and disposal sites as well as unplanned release sites

- Preoperational monitoring of new or modified facilities that have the potential to adversely affect the environment

- Monitoring of operating or standby facilities

- Monitoring of facilities in the process of demolition or remediation.

The monitoring scope for these categories includes the collection of ambient air, water, sediment, aquatic vegetation, soil, biota, external radiation measurements, and radiological surveys. 


\subsection{APPLICABILITY TO WESTINGHOUSE HANFORD COMPANY QUALITY ASSURANCE PROGRAM}

This QAPjP applies specifically to the sampling and analys is activities and monitoring performed for all OEM program activities conducted by WHC.

This QAPjP is prepared in accordance with the guidance of Interim Guidelines and Specifications for Preparing Quality Assurance Project Plans, QAMS-005/80 (EPA 1983), and "Quality Assurance Methods," 40 CFR 61, Appendix B, Method 114, as required by the Environmental Regulatory Guide for Radiological Effluent Monitoring and Environmental Surveillance, DOE/EH-0173T. It describes the means selected to implement the overall QA program requirements defined in the Quality Assurance Manual, WHC-CM-4-2. The implementing procedures, $\mathrm{plans,}$ and instructions are appropriate for the control of the OEM program, which requires compliance with DOE, EPA, state, and $10 \mathrm{cal}$ requirements.

The QAPJP uses a matrix of procedural resources from facility or Hanford Site manuals used in the OEM program. This QAPJP shall be reviewed and updated as required when changes are made in the OEM program. Distribution and revision control of this plan shall be in compliance with WHC-CM-3-6, Uniform Publications System, PS-2-02, "External Publication." Review/approval personnel indicated on the title page of the document and other individuals designated by Environmental Monitoring and Investigations (EMI) shall have distribution and revision control. Plans and procedures referenced in the QAPjP are available on request for regulatory review. 
WHC-EP-0538-2

\subsection{PROJECT ORGANIZATION AND RESPONSIBILITIES}

\subsection{PROJECT MANAGEMENT}

WHC's Hanford Technical Services (HTS) function has the responsibility for specifying OEM program requirements. Responsibilities of key personnel are described below.

- Hanford Technical Services/Environmental Monitoring and Investigations. The EMI group within HTS has the responsibility to plan, direct, and verify the OEM program at WHC facilities, unplanned release sites, and associated active and inactive waste storage and disposal sites as required to ensure compliance to environmental requirements.

The EMI function acts as the technical liaison between WHC facilities, other DOE contractors, regulators, and other interested parties. The EMI also provides technical support for operational environmental sampling and analysis. The EMI performs trend analys is and prepares annual operational monitoring reports for distribution to WHC facilities, DOE contractors, regulators, and other interested parties. The EMI assigns sample numbers and identification numbers for each sample point. The EMI maintains the permanent records of operational samples. The EMI also ensures that the QAPJP and associated documentation are updated.

- Radiological Control/Site Surveillance. The Site Surveillance group within Radiological Control (RC) has the responsibility to provide. sampling and monitoring support as defined in the OEM program. The Bechtel Hanford, Inc. The RC group has the responsibility to provide radiation surveys of inactive waste sites and facilities under its control.

\subsection{SUPPORTING ORGANIZATIONS}

- Facility Manager. The facility manager has the responsibility to maintain the facility in an environmentally safe condition, be responsive to environmental problems or concerns raised about the facility, and provide corrective action to these problems or concerns.

- Quality Assurance. Provides quality engineering support to meet procurement control, document approval, surveillance, and auditing needs.

- Environmental Services/Effluent Monitoring. The EM group has the responsibility to oversee and verify the environmental radioactivity and chemical emission monitoring program at WHC facilities as required to ensure compliance with environmental regulations.

- Procurement. The procurement organization obtains services and/or contracts in accordance with purchase requisitions, purchase orders, 
drawings, contracts, specifications, or instructions used to define requirements for a purchase.

- Environmental Policy. These personnel provide guidance in interpreting all regulations and coordination with pertinent regulatory agencies and establishes and maintains WHC-CM-7-5, Environmental Compliance Manual.

- Analytical Services. Provides data package validation as requested by EMI.

\subsection{ANALYTICAL LABORATORIES}

Analytical samples will be transported to an approved WHC participant contractor or subcontractor laboratory for radiological and/or chemical analysis. For participant contractors or subcontractors, applicable quality requirements of this QAPJP shall be invoked as part of the approved applicable work order, letter of instruction, or procurement document. Laboratories are to submit their analytical methods and internal QA Program for WHC review and approval before use.

At the direction of EMI, laboratories may be procured for split (performance audit) sample analysis. Participant contractor or subcontractor laboratories will be subject to a source surveillance with Environmental QA participation, in compliance with Quality Instruction (QI) 7.3, "Source Surveillance and Inspection" (WHC-CM-4-2). Surveillances shall be in compliance with QI 10.4, "Surveillance" (WHC-CM-4-8).

\subsection{OTHER SUPPORT CONTRACTORS}

The EMI may procure the services of other subcontractors to support any or all of the activities addressed by this QAPJP. Such activities shall be in compliance with Westinghouse-Hanford-approved QA plans and/or procedures, subject to the controls of QI 7.3, "Source Surveillance and Inspection" (WHC-CM-4-2). 
WHC-EP-0538-2

\subsection{QUALITY ASSURANCE OBJECTIVES FOR MEASUREMENTS}

The QA objectives for measurements generally applicable to the OEM program under the purview of this QAPJP are related primarily to the following:

- Defining appropriate methods for sampling and analysis for the required analytes of interest

- Defining quantitation limits and values for analytical precision and accuracy appropriate for the purposes of all operational environmental monitoring.

- Defining data representativeness, completeness, and comparability in terms applicable to the OEM program.

Detailed discussions of the analytes of interest and analytical methods are provided in Table 4-1. Specific data-quality needs for individual investigations shall be addressed at the time of the need. Other measurement considerations, accuracy requirements, units, and data recording/reporting protocols for instruments supporting operational environmental monitoring and other types of special monitoring investigations shall be specified in the applicable procedures discussed herein and in the laboratory statements of work: Service Provided by the 222-S Laboratory for Regulatory Support, WHC-SP-0689 (Thomas 1993), Statement of Work for Services Provided by the Waste Sampling and Characterization Facility for Effluent Monitoring, WHC-EP-0835 (Gleckler 1995), and Pacific Northwest Laboratory (PNL) Contract Number 163589-A-M1.

\subsection{ANALYTES OF INTEREST AND ANALYTICAL METHOD SELECTION}

Table 4-1 identifies potential analytes of interest and corresponding analytical reference methods for operational environmental sampling and monitoring at the Hanford Site. The list of analytes specifies reference methods selected from the appropriate EPA and DOE guidance documents. (See notes $a, d, e, f, g$, and $h$ of Table 4-1.) Where options have been suggested or implied, the more reliable methods have been selected.

The WHC laboratories typically perform radiological analyses of all samples submitted as well as analyses of nonradioactive constituents in liquid samples from effluent ponds associated with the OEM program. The offsite analytical laboratory performs low-level radiological analyses of routine operational environmental samples and is required to meet the contractual requirements established by WHC and PNL.

\subsection{CONTRACTUAL QUANTITATION LIMITS AND RANGES FOR ANALYTICAL PRECISION AND ACCURACY}

The performance of the analytical laboratory or laboratories providing support to the OEM program shall be subject to EPA-established method- and analyte-specific quantitation limits and ranges for precision and accuracy (EPA 1972, EPA 1977). These parameters are presented as target values that 
WHC and the proposed laboratory must adjust and/or confirm and accept before the final approval of an associated subcontract, work order, or statement of work.

\subsection{REPRESENTATIVENESS, COMPLETENESS, AND COMPARABILITY}

The specifications of location and intervals in WHC-CM-7-4, Environmental Monitoring address qualitative goals for data representativeness. Completeness objectives for the OEM program shall require that the contractually or procedurally established requirements for the precision and accuracy be met annually for at least 90 percent of the requested determinations for each laboratory conducting analyses. This means that precision and accuracy for a11 operational environmental monitoring data shall be at least 90 percent effective, accurate, and precise overall.

Failure to meet this criterion shall be documented in data summary reports and shall be considered in validation process. Corrective action measures using specific procedures shall be initiated by EMI, Analytical Services or QA, as appropriate. Approved analytical procedures shall require the use of the reporting techniques and units consistent with the EPA reference methods listed in Table 4-1 to facilitate data-set comparability in terms of precision and accuracy. 
Table 4-1. Preferred Analytical Methods.

\begin{tabular}{|c|c|c|c|}
\hline $\begin{array}{l}\text { Analytical } \\
\text { Category }\end{array}$ & $\begin{array}{l}\text { Analyte of } \\
\text { Interest }\end{array}$ & $\begin{array}{c}\text { Standard EPA } \\
\text { Reference Method }\end{array}$ & $\begin{array}{l}\text { Analytical } \\
\text { Method }^{c}\end{array}$ \\
\hline \multirow[t]{3}{*}{ Ions/Anions } & Nitrate & $352.1^{d}$ & $b$ \\
\hline & Nitrite & $354.1^{d}$ & $b$ \\
\hline & $\begin{array}{l}\text { Ph/Total } \\
\text { Dissolved } \\
\text { Solids (TSD) }\end{array}$ & $9045^{d}$ & $b$ \\
\hline \multirow[t]{22}{*}{ Radionuclides } & & & \\
\hline & Gross Alphak & $9310^{a}$ & $b$ \\
\hline & Gross Beta ${ }^{j}$ & $9310^{a}$ & $b$ \\
\hline & $\begin{array}{l}\text { Uranium } \\
(238,239,240)\end{array}$ & $00-07^{f}$ & $b$ \\
\hline & $\begin{array}{l}\text { Uranium } \\
233,234\end{array}$ & $00-07^{f}$ & $b$ \\
\hline & Uranium 235 & $00-07^{f}$ & b \\
\hline & $\begin{array}{l}\text { Plutonium } \\
\oint(238,239,240)\end{array}$ & $00-07^{e}$ & $b$ \\
\hline & Plutonium 241 & $00-07^{e}$ & $b$ \\
\hline & $\begin{array}{l}\text { Americium } \\
241,243\end{array}$ & $A M-01^{e}$ & $b$ \\
\hline & $\begin{array}{l}\text { Strontium } \\
89 / 90\end{array}$ & $S R-05^{f}$ & $b$ \\
\hline & Tritium & $707^{\mathrm{h}}$ & $b$ \\
\hline & Technetium 99 & $E C-186^{i}$ & $b$ \\
\hline & Cesium 137 & NA & $b$ \\
\hline & Cesium 134 & NA & $b$ \\
\hline & Cesium 135 & NA & $b$ \\
\hline & Iodine 129 & NA & $b$ \\
\hline & Cerium 144 & NA & $b$ \\
\hline & Carbon 14 & NA & $b$ \\
\hline & Ruthenium 103 & NA & b \\
\hline & Ruthenium 106 & NA & b \\
\hline & Selenium & NA & b \\
\hline & Coba7t $60 / 58$ & NA & $b$ \\
\hline
\end{tabular}


Table 4-1. Preferred Analytical Methods.

\begin{tabular}{|l|l|c|c|}
\hline $\begin{array}{c}\text { Analytical } \\
\text { Category } \\
\text { Radionuclides } \\
\text { (cont) }\end{array}$ & $\begin{array}{c}\text { Analyte of } \\
\text { Interest }\end{array}$ & $\begin{array}{c}\text { Standard EPA } \\
\text { Reference Method }\end{array}$ & $\begin{array}{c}\text { Analytical } \\
\text { Method }^{c}\end{array}$ \\
\cline { 2 - 4 } & $\begin{array}{l}\text { Zirconium } \\
93 / 95\end{array}$ & NA & b \\
\cline { 2 - 4 } & $\begin{array}{l}\text { Tin } \\
124,125,126\end{array}$ & NA & b \\
\cline { 2 - 4 } & Nicke1 63 & NA & b \\
\cline { 2 - 4 } & Neptunium 237 & $00-07^{\mathrm{e}}$ & b \\
\cline { 2 - 4 } & Thorium 230 & $00-07^{f}$ & b \\
\cline { 2 - 4 } & Samarium 151 & NA & b \\
\cline { 2 - 4 } & Iron 59 & NA & b \\
\cline { 2 - 4 } & Lead 212/210 & NA & b \\
\cline { 2 - 4 } & Antimony 113 & NA & b \\
\cline { 2 - 4 } & $\begin{array}{l}\text { Promethium } \\
147\end{array}$ & NA & b \\
\cline { 2 - 4 } & $\begin{array}{l}\text { Europium } \\
154,155\end{array}$ & NA & b \\
\hline
\end{tabular}

a Standard EPA methods are from Iest Methods for Evaluating Solid Waste (SW846) (EPA 1986).

Analytical methods shall be WHC or WHC-approved participant contractor or subcontractor procedures based on the reference methods cited in Column 3 . All procedure reviews and approvals shall be in compliance with applicable WHC procedure control or procurement procedures, as noted in Section 3.0. Once laboratory methods are approved, this table shall be updated to provide contractual method references as appl icable.

Analysis shall be performed by an approved WHC, participant contractor, or Subcontractor laboratory.

Standard methods are from Methods for Chemical Analys is of Water and Waste (EPA 1979).

Standard methods are from Prescribed Procedures for the Measurement of Radioactivity drinking water (EPA 1992).

Standard Methods are from Eastern Environmental Radiation Facility Radiochemistry Profedures Manual (EPA 1984 )

9u is calculated from ${ }^{239} \mathrm{Pu}$; the cognizant facility personnel provide the isotopic weight pergent of plutonium 239, 240, and $3 \xi 1$ produced: Activity ration is: $5\left\{\right.$ yeight percent $\left.\left.{ }^{24} \mathrm{Pu}\right)(103.2)\right] /\left[\left(\right.\right.$ (weight percent $\left.\left.{ }^{239} \mathrm{Pu}\right)(0.0614)\right)+($ (weight percent

Pu $\{(8.227))]$ where specific activities are:

$240 \mathrm{Pu}=0.0614 \mathrm{Ci} / \mathrm{g}$

$241 \mathrm{Pu}=0.227 \mathrm{Ci} / \mathrm{g}$

Ihgreffre, the quarterly concentration of $241_{\mathrm{Pu}}$ is [(quarterly concentration of $239 / 240 \mathrm{Pu} \mu \mathrm{Ci} / \mathrm{ml}$ ) (activity ratio)]

${ }^{h}$ standard method is from Standard Methods for the Examination of Water and Waste Water (APHA 1985).

Standard method is from The Environmental Survey Manual, ABRendix D (DOE 1987).

$\mathrm{j}_{\text {The values shown for gross beta activity may be used when }}{ }^{80} \mathrm{Sr}$ is known to be the

post limiting beta emitter present.

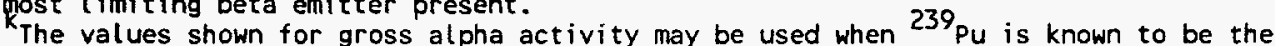
post limiting alpha emitter present.

Precision is based on established contractual values. Accuracy is within $\pm 25 \%$. 
Table 4-2. Supporting Procedures for the Operational Environmental Monitoring Program.

\begin{tabular}{|c|c|c|}
\hline Procedure & Procedure Number & Title \\
\hline $\begin{array}{l}\text { Chain of Custody and } \\
\text { Sample Packaging and } \\
\text { Shipping }\end{array}$ & $\begin{array}{l}\text { WHC-CM-7-4, Section } 4 \\
\text { WHC-IP-0718 }\end{array}$ & $\begin{array}{c}\text { Procedure Verification } \\
\text { Various Titles }\end{array}$ \\
\hline \multirow[t]{10}{*}{$\begin{array}{l}\text { Sampling and } \\
\text { Monitoring }\end{array}$} & $\begin{array}{l}\text { WHC-CM-7-4, Section } 5 \\
\text { WHC-IP-0718 }\end{array}$ & $\begin{array}{l}\text { Air Sampling } \\
\text { Various Titles }\end{array}$ \\
\hline & $\begin{array}{l}\text { WHC-CM-7-4, Section } 6 \\
\text { WHC-IP-0718 }\end{array}$ & $\begin{array}{l}\text { Soil Sampling } \\
\text { Various Titles }\end{array}$ \\
\hline & $\begin{array}{l}\text { WHC-CM-7-4, Section } 7 \\
\text { WHC-IP-0718 }\end{array}$ & $\begin{array}{l}\text { Vegetation Sampling } \\
\text { Various Titles }\end{array}$ \\
\hline & $\begin{array}{l}\text { WHC-CM-7-4, Section } 8 \\
\text { WHC-IP-0718 }\end{array}$ & $\begin{array}{l}\text { Animal Sampling } \\
\text { Various Titles }\end{array}$ \\
\hline & $\begin{array}{l}\text { WHC-CM-7-4, Section } 9 \\
\text { WHC-IP-0718 }\end{array}$ & $\begin{array}{l}\text { Surface Water Sampling } \\
\text { Various Titles }\end{array}$ \\
\hline & WHC-CM-7-4, Section 10 & Groundwater Monitoring \\
\hline & $\begin{array}{l}\text { WHC-CM-7-4, Section } 11 \\
W H C-I P-0718\end{array}$ & $\begin{array}{l}\text { Background Radiation } \\
\text { Various Titles }\end{array}$ \\
\hline & $\begin{array}{l}\text { WHC-CM-7-4, Section } 12 \\
\text { WHC-IP-0718 }\end{array}$ & $\begin{array}{l}\text { Radiological Surveys } \\
\text { Various Titles }\end{array}$ \\
\hline & $\begin{array}{l}\text { WHC-CM-7-4, Section } 13 \\
\text { WHC-IP-0718. }\end{array}$ & $\begin{array}{l}\text { Special and Emergency } \\
\text { Sampling } \\
\text { Various Titles }\end{array}$ \\
\hline & WHC-IP-0718 & Various Titles \\
\hline Calibration & WHC-IP-0718 & Various Titles \\
\hline
\end{tabular}




\subsection{SAMPLING PROCEDURES}

\subsection{SAMPLING PROCEDURES}

Sampling activities, equipment, material, and containers will be subjected to field screening (i.e., radiological survey and quality control check of transportation documentation) for radioactivity. This screening shall be in compliance with the requirements governing radiation permits to ensure that samples are transported only to appropriately equipped and licensed laboratories. All environmental monitoring sampling conducted in support of the OEM program will be performed in a manner that provides representative samples of radioactive materials in near-field environmental media from operations at the Hanford Site.

\subsection{OTHER SUPPORTING PROCEDURES}

Except for the analytical chemistry procedures specified in Table 4-1, procedures to be used to support 0 EM program activities directly are presented in Table 4-2, cross referenced to their source documents and the types of activities they typically will support.

\subsection{PROCEDURE APPROVALS AND CONTROL}

\subsubsection{Westinghouse Hanford Procedures}

The WHC procedures that may be used to support the OEM program sampling and monitoring activities are referenced in Table 4-2. Latest approved versions of a 11 referenced procedures shall apply in all cases. Selected manuals include WHC-CM-7-4, WHC-IP-0718, Health Physics Procedures (WHC 1993), BHI-EE-02, Rev. 0, Environmental Requirements (BHI 1995), Section 7.0, and WHC-CM-4-2. All procedures are available on request at the direction of EMI.

\subsubsection{Participant Contractor/Subcontractor Procedures}

As noted in Section 3.4, participant contractor and/or subcontractor services may be procured with the concurrence of the EMI manager. Such procurement shall be subject to the applicable requirements of WHC-CM-4-2.

Whenever such services require procedural controls, use of WHC procedures, or submittal of contractor procedures for WHC review and approval before use, such requirements shall be included in the procurement document or work order. In addition to submitting analytical procedures, analytical laboratories shall be required to submit the current version of their QA plans. 


\subsection{PROCEDURE ADDITIONS AND CHANGES}

Additional procedures or changes to existing procedures that are necessary to accommodate unforseen field situations may be authorized in accordance with Section 4.0, "Procedure Verification" of the WHC-CM-7-4.

\subsection{SAMPLING SCHEDULE}

A Routine Operational Environmental Monitoring Schedule is issued annually. It includes the schedule of radiation surveys, sampling to be performed, and sampling frequency.

The EMI writes and approves the radiation survey and sampling schedules. The EMI shall approve any changes to the schedule, including temporary or onetime deviations, in accordance with WHC-CM-7-4. 


\subsection{SAMPLE CUSTODY}

All samples obtained during OEM program activities shall be controlled as required by WHC-CM-7-4, Section 4, "Procedure Verification." These requirements apply as soon as the sample is introduced to the sample container.

Other requirements for specific samples are given in the WHC-CM-7-4. These requirements shall ensure the maintenance of sample integrity and identification from receipt through completion of the analytical process.

Requirements for returning residual sample materials after analysis shall be defined in the procurement documentation or work orders to subcontractor or participant contractor laboratories. Analysis results shall be traceable to original samples through unique sample numbers or identification codes. All analyses results shall be controlled as permanent project quality records, as required by QA/QC Requirement (QR) 17.0, "Quality Assurance Records" (WHC-CM-4-2) and Section 4, "Operational Environmental Monitoring" (WHC-CM-7-5), "Procedure Verification" (WHC-CM-7-4), Document Control and Records Management, WHC-CM-3-5, or equivalent WHC procedures. 


\subsection{CALIBRATION PROCEDURES}

Calibration of all WHC measuring and test equipment, whether in the existing inventory or purchased for operational environmental monitoring, shall be controlled as required by the WHC-4-2, QR 12.0, "Control of Instrument."

Calibration and maintenance are the controlling factors in this system. Routine operational checks for WHC field equipment shall be as defined in internal WHC procedures; similar information shall be provided within WHCapproved participant contractor or subcontractor procedures. The sampling and monitoring equipment used in this activity is controlled by the ComponentBased Recall Calibration System or another WHC-approved system.

Calibration procedures can be made available under the direction of the EMI manager. 


\subsection{ANALYTICAL PROCEDURES}

Analytical methods or procedures based on the reference methods identified in Section 4.0 shall be selected or developed and approved before use, in compliance with appropriate WHC procedure, work order, and/or procurement control requirements (Section 5.3.2).

All participating contractors or subcontractors qual ity-affecting records shal1 be retained in compliance with WHC-CM-4-2, QR 17.0, "Qual ity Assurance Records," and QI 17.1, "Quality Assurance Record Control." A11 such documents will be made available on request at EMI's direction. 


\section{WHC-EP-0538-2}

\subsection{MONITORING AND REPORTING CRITERIA}

The criteria for $0 E M$ program sampling, monitoring, and reporting are identified in WHC-CM-7-4 and WHC-CM-7-5. 
WHC-EP-0538-2

\subsection{DATA REDUCTION, VALIDATION, AND REPORTING}

\subsection{DATA REDUCTION AND DATA PACKAGE PREPARATION}

Analytical laboratories shall be responsible for preparing both a report summarizing the analysis results and a detailed data package. The data package shall include information necessary to perform data validation to the extent indicated by the minimum requirements.

Data reporting requirements and data package content shall comply with the appropriate requirements of Test Methods for Evaluating Solid Wastes, SW-846-1 (EPA 1992). These requirements shall be defined in work order or procurement documentation, subject to WHC review and approval as noted in Section 4.2.

Data packages shall be prepared in legible, reproducible format; any changes must be made as single-line corrections in black, nonsoluble ink; changes must be initialed and dated.

Other supporting information (such as initial calibration data, reconstructed ion chromatographies, spectrograms, and raw data) need not be included in the submittal of individual data packages unless specifically requested by EMI.

The analytical laboratory shall retain all sample data and make it available for system or program audits at the request of WHC, EPA, the U.S. Department of Energy, Richland Operations Office (RL), WDOH representatives, or other regulatory agencies. The analytical laboratory shall retain such data through the duration of the authorization work order or for the period of their contractual statement of work, when it shall be turned over to WHC or the contract administrator for archiving.

The analytical laboratory's QA manager shall review and approve the completed data package before submittal for validation. The requirements of this section shall be included in procurement documentation or work orders, as appropriate, in compliance with the standard WHC procurement control procedures referenced in Section 3.0 .

\subsection{VALIDATION}

The EMI shall verify and validate completed data packages for radioactive operational environmental samples when requested. Analytical Services may be requested to validate the completed data packages for hazardous or nonradioactive operational environmental samples. Alternative sources may be used as directed by EMI. Regardless of the source of validation services, validation requirements shall be defined with WHC-approved data validation procedures, which at a minimum shall require the following quality control (QC) checks.

For organic analyses, validation reports shall be prepared documenting QC checks as recommended in Laboratory Data Validation Functional Guidelines for Evaluating Organics Analyses (EPA 1988a). 
For inorganic analyses, validation reports shall be prepared documenting QC checks as recommended in Laboratory Data Validation Functional Guidelines for Evaluating Inorganics Analyses (EPA 1988b).

Validation procedures for radionuclides and other types of analyses shall include requirements for QC checks with similar levels of detail.

The level of confidence in the data resulting from the radiological analyses shall be estimated by analyzing blanks and spiked pseudosamples (EPA-designated environmental measurement laboratory program) and by comparing the resulting concentration estimates to the known concentrations in those samples. The precision of radionuclide analytical results shall be reported as a range, a variance, a standard deviation, a standard error, and/or a confidence interval. When selecting the data to be considered, outliers shall be excluded from the data only after investigation confirms that an error has been made in the sample collection, preparation, measurement, or data analysis process. As new data are received, they shall be compared to earlier data.

\subsection{FINAL REVIEW AND RECORDS MANAGEMENT CONSIDERATIONS}

EMI will perform a final technical review of validation reports and supporting analytical data packages before submittal to the customer or inclusion in reports or technical memoranda. Records management practices shall comply with QR 17.0, "Quality Assurance Records" (WHC-CM-4-2). 


\subsection{INTERNAL QUALITY CONTROL}

In general, analytical samples shall be subject to in-process quality control measures in both the field and the laboratory. The following minimum field quality control requirements apply to routine operational environmental monitoring samples. These requirements are adapted from those recommended by the EPA Office of Enforcement, as well as those of the research and development contractor, where practical. Radiological Control uses procedures described in WHC-IP-0718 (WHC 1993).

\subsection{REPLICATE SAMPLING}

Collecting replicate samples and analyzing them is the primary means of determining whether variability is caused by sampling error.

Replicate samples shall be collected for all sampled media. At least one replicate sample shall be collected for each medium at the required frequency.

\subsection{LABORATORY ANALYSES}

The OEM program depends on the data received from analytical laboratories. A procedure verification program is vital to environmental sample analyses. This procedure verification effort consists of analytical standards, adherence to written sampling procedures, procedural audits, and record keeping.

The following companies whose services are controlled in accordance with procedures in WHC-CM-4-2, QR 4.0, provide laboratory support to the OEM program sampling program:

1. Offsite Laboratory. This laboratory analyzes environmental soil, vegetation, biota, and air samples, as well as other selected samples.

2. Westinghouse Hanford Company. The analytical laboratories analyze air filter samples and the sediment, water, and aquatic vegetation samples from the liquid disposal sites.

3. Radiation Standards and Engineering at Pacific Northwest Laboratory. The Calibration Laboratory at PNL reads, tests, calibrates, and packages the thermoluminescent dosimeters.

4. Internal Laboratory Quality Control Programs. A11 1aboratories maintain internal quality control programs that address practices such as:

- Routine calibration of counting instruments

- Routine source and background counts

- Routine yield determination of radiochemical procedures

- Replicate analyses to check precision

- Analysis of quality control standards

- Analysis of reagent blanks to verify chemical purity. 


\section{WHC-EP-0538-2}

5. National Standards Program. The laboratories performing the environmental analyses use standards traceable to the National Institute of Standards and Technology, when available, to ensure the accuracy of radionuclide determinations.

Other requirements specific to laboratory analytical equipment calibration are included in Section 7.0. The minimum requirements of this section shall be invoked in procurement documents or work orders in compliance with standard WHC procedures as noted in Section 5.3.2. The statement of work should be reviewed by the laboratory to ensure that the laboratory is capable of performing the work. 


\subsection{SYSTEM AUDITS}

Audits shall be performed to verify the quality of operation of one or more elements of the total measurement system. In the sense intended by QAMS-005/80 (EPA 1983), system audits involve a qualitative onsite evaluation of laboratories (or other organizational elements of the measurement system) for compliance with established QA program and procedure requirements. This also includes audits of individual facility sampling programs against those requirements in the OEM program.

The appropriate organization shall perform system audits; system audit requirements shall be implemented through the use of procedure QI 10.4, "Surveillance" (WHC-CM-4-2). Additiona1 performance or system audits shal1 be conducted if specifically required by the OEM program, as a consequence of corrective action requirements, or if requested by QA, RL, EPA, or WDOH.

Any discrepancies observed while evaluating performance audit results or during system audit surveillance activities that cannot be corrected immediately to the satisfaction of the investigator shall be documented.

In addition, at the direction of the QA officer, all aspects of test activities also may be evaluated as part of the WHC sitewide QA audits conducted in compliance with QR 18.0, "Audits"; QI 18.1, "Audit Programming and Scheduling" (WHC-CM-4-2); Quality Assurance Instruction (QAI) 18.1, "Planning, Performing, Reporting, and Follow-up and Closure of Quality Audits" (WHC-CM-4-8) . 


\subsection{PREVENTIVE MAINTENANCE}

Measurement and testing equipment used in the field and laboratory that directly affect the quality of the analytical data shall be subject to preventive maintenance that ensure measurement systems have minimal downtime and produce reliable measurements. Field equipment maintenance instructions shall be as defined by the approved procedures governing equipment use.

Laboratories shall be responsible for performing or managing the maintenance of their analytical equipment; maintenance requirements, spare parts lists, and instructions shall be included in individual methods or in laboratory QA Plans, subject to WHC review and approval as noted in Sections 3.3 and 4.2 . 
WHC-EP-0538-2

\subsection{DATA ASSESSMENT PROCEDURES}

Data from environmental media sampling and monitoring shall be assessed as required by the OEM program and appropriate statistical evaluation techniques that may be referenced therein. The laboratory first shall compile the analytical data, and validate it in compliance with WHC-approved procedures meeting the minimum requirements of Section. 10.0 . 


\subsection{CORRECTIVE ACTION}

Requests for corrective action required as a result of surveillance or audit activity shall be documented and dispositioned as required by QR 15.0 , "Control of Nonconforming Items"; QI 15.1, "Nonconforming Item Reporting"; QI 15.2, "Nonconformance Report Processing"; QR 16.0, "Corrective Action"; QI 16.1, "Trend Analysis"; 16.2, "Corrective Action Request" (WHC-CM-4-2); QI 10.4, "Surveillance"; QAI 18.1, "Planning, Performing, Reporting, Followup, and Closure of Quality Audits" (WHC-CM-4-8); and WHC-CM-7-4.

The EMI responsibilities for corrective-action follow-up and resolution are contained in WHC-CM-7-4. Other measurement systems, procedures, or plan corrections that may be required as a result of routine review processes shall be resolved as required by governing procedures or shall be referred to EMI for resolution. Copies of all surveillance nonconformance, audit, and corrective-action documentation shall be maintained on completion or closure by the surveilling/auditing organization. The project QA records location shall be specified by EMI. 


\subsection{QUALITY ASSURANCE REPORTS}

As stated in Sections 11.0 and 12.0, OEM program activities shall be assessed regularly by surveillance and auditing processes. Surveillance, nonconformance, audit, and corrective action documentation shall be considered $Q A$ records and shall be documented and dispositioned as stated in Section 15.0. Records management requirements applicable to subcontractors or participant contractors sha11 be defined in applicable procurement documents or work orders as noted in Section 5.3.2. 
WHC-EP-0538-2

\subsection{REFERENCES}

40 CFR 61, 1989, "National Emission Standards for Hazardous Air Pollutants," Code of Federal Regulations, as amended.

40 CFR 70, 1991, "Operating Permit Program," Code of Federal Regulations, as amended.

40 CFR 264, 1988, "Standards for Owners and Operators of Hazardous Waste Treatment, Storage, and Disposal Facilities," Code of Federal Regulations, as amended.

40 CFR 265, 1992 "Interim Status Standards for Owners and Operators of Hazardous Waste Treatment, Storage, and Disposal Facilities," Code of Federal Regulations, as amended.

40 CFR 302, 1988, "Designation, Reportable Quantities, and Notification," Code of Federal Regulations, as amended.

APHA, 1985, Standard Methods for the Examination of Water and Wastewater, 16th edition, American Public Health Association, American Water Works Association, and Water Pollution Control Federation, Washington, D.C.

BHI, 1995, Environmental Requirements, BHI-EE-02, Rev. 0, Bechtel Hanford, Inc., Richland, Washington.

Comprehensive Environmental Response, Compensation and Liability Act of 1980 , as amended, 42 USC 9601 et seq.

DOE, 1981, Environmental Protection, Safety, and Health Protection Information Reporting Requirements, DOE Order 5484.1, U.S. Department of Energy, Washington, D.C.

DOE, 1987, The Environmental Survey Manua7, Appendix D, U.S. Department of Energy/Office of Environmental Audit, Washington, D.C.

DOE, 1988a, General Environmental Protection Program, DOE Order 5400.1, U.S. Department of Energy, Washington, D.C.

DOE, 1988b, Radioactive Waste Management, DOE Order 5820.2A, U.S. Department of Energy, Washington, D.C.

DOE, 1990, Radiation Protection of the Public and the Environment, DOE Order 5400.5, U.S. Department of Energy, Washington, D.C.

DOE, 1991, Environmental Regulatory Guide for Radiological Effluent Monitoring and Environmental Surveillance, DOE/EH-0173T, U.S. Department of Energy, Washington, D.C.

DOE-RL, 1994, Radioactive Waste Management, DOE/RL-91-50, Rev. 1, U.S. Department of Energy, Richland Operations Office, Richland, Washington. 
EPA, 1972, Handbook for Analytical Quality Control in Water and Wastewater Laboratories, U.S. Environmental Protection Agency, Washington, D.C.

EPA, 1977, Handbook for Analytical Quality Control in Radioanalytical Laboratories, EPA-600/7-77/088, U.S. Environmental Protection Agency, Washington, D.C.

EPA, 1979, Methods for Chemical Analysis of Water and Wastes, EPA-600/4-79-020, U.S. Environmental Protection Agency/Environmental Monitoring and Support Laboratory, Cincinnati, Ohio.

EPA, 1982, Prescribed Procedures for the Measurement of Radioactivity in Drinking Water, EPA 600/4-80-032, U.S. Environmental Protection Agency/Office of Exploratory Research, Washington, D.C.

EPA, 1983, Interim Guidelines and Specifications for Preparation of Quality Assurance Project Plans, QAMS-005/80, U.S. Environmental Protection Agency/Office of Exploratory Research, Washington, D.C.

EPA, 1984, Eastern Environmental Radiation Facility (EERF) Radiochemistry Procedures Manua7, EPA 520/5-84-006, U.S. Environmental Protection Agency, Washington, D.C.

EPA, 1988a, Laboratory Data Validation Functional Guidelines for Evaluating Organics Analyses, Hazardous Site Evaluation Division, U.S. Environmental Protection Agency, Washington, D.C.

EPA, 1988b, Laboratory Data Validation Functional Guidelines for Evaluating Inorganics Analyses, Hazardous Site Evaluation Division,

U.S. Environmental Protection Agency, Washington, D.C.

EPA, 1989, "USEPA Contract Laboratory Program Statement of Work for Inorganic Analysis," Federal Register, Vo1. 54, No. 13, Sample Management Office, U.S. Environmental Protection Agency, Washington, D.C.

EPA, 1992, Test Methods for Evaluating Solid Wastes, SW-846, Third Edition, U.S. Environmental Protection Agency/Office of Solid Waste and Emergency Response, Washington, D.C.

Gleckler, B. P., 1995, Statement of Work for Service Provided by the Waste Sampling and Characterization Facility for Effluent Monitoring, WHC-EP-0835, Westinghouse Hanford Company, Richland, Washington.

Thomas, S. P., 1993, Services Provided by the 222-S Laboratory for Regulatory Support, WHC-EP-0689, Westinghouse Hanford Company, Richland, Washington.

WAC 173-303, 1990, "Dangerous Waste Regulations," Washington Administrative Code, as amended.

WAC 246-247, 1990, "Radiation Protection Standards," Washington Administrative Code, as amended.

WHC-CM-3-5, Document Control and Records Management, Westinghouse Hanford Company, Richland, Washington. 
WHC-CM-3-6, Uniform Publications System, Westinghouse Hanford Company, Richl and, Washington.

WHC-CM-4-2, Quality Assurance Manual, Westinghouse Hanford Company, Richland, Washington.

WHC-CM-4-8, Quality Assurance Instructions, Westinghouse Hanford Company, Richland, Washington.

WHC-CM-7-4, Operational Environmental Monitoring, Westinghouse Hanford Company, Richland, Washington.

WHC-CM-7-5, Environmental Compliance Manual, Westinghouse Hanford Company, Richland, Washington.

WHC-CM-8-2, Central Support Services, Westinghouse Hanford Company, Richland, Washington.

WHC, 1991, A Guide for Preparing Hanford Site Facility Effluent Monitoring Plans, WHC-EP-0438, Westinghouse Hanford Company, Richland, Washington.

WHC, 1993, Health Physics Procedures, WHC-IP-0718, Westinghouse Hanford Company, Richland, Washington. 
WHC-EP-0538-2

This page intentionally left blank.

. 
WHC-EP-0538-2

\section{DISTRIBUTION}

\section{Number of copies}

ONSITE

11

U.S. Department of Energy, Richland Operations office

G. M. Bell

E. A. Bracken

A5-52

M. J. Furman

A5- 19

J. B. Hall

S7 -55

R. D. Hildebrand

A5-55

R. A. Holten

A5-55

R. 0. Puthoff

H4-83

W. B. Scott

S7 -41

A5-55

S. D. Stites

$\mathrm{N} 2-36$

D. C. Ward

Public Reading Room

A5-55

Al-65

Westinghouse Hanford Company

M. R. Adams

H6-01

L. P. Diediker

S3-95

J. J. Dorian (2)

C. J. Geier

S3-24

R. E. Heineman, Jr.

$\mathrm{R} 2-36$

S. M. Mckinney

$\mathrm{K} 8-37$

S3-95

R. A. Meznarich

$\mathrm{H} 6-30$

C. J. Perkins (10)

$\mathrm{XO}-21$

L. R. Richterich

$\mathrm{H} 6-20$

M. D. Rowe

J. W. Schmidt (2)

J. A. Seamans

$\mathrm{T} 1-25$

$\mathrm{T} 1-30$

N2-04

L. D. Sparks

S3-90

R. R. Thompson

L4-96

R. L. Watts

L6-52

D. J. Watson

$\times 0-41$

Central Files

Environmental Data Management

Center

A3 -88

Environmental Resource Center

$\mathrm{H} 4-22$

H4 -55

OSTI (2)

A3-36

Bechtel Hanford Incorporated

L. A. Mihalik (2)

H4-79 
WHC-EP-0538-2

This page intentionally left blank.

Dist-2 